and additional channels obtained. In addition, if telegraph circuits are required, carrier telegraph systems may be operated in place of one or more of the telephone channels. For example, with the six telephone channels, a possible arrangement would be to employ two of these channels for carrier telegraph circuits. The cable could then carry simultaneously a load of four telephone messages and twenty-four or more two-way telegraph messages.

\section{Medical Uses of Radium}

THE Medical Research Council has issued a report which summarises the results of research work in the treatment of cancer done during 1930 by means of radium salt entrusted by H.M. Government to the Council (Special Rep. Series, No. 160. London : H.M. Stationery Office. Is. net). It also contains data concerning patients treated in earlier years, and thus maintains continuity with the eight previous and similar reports that have been issued. The stock of radium entrusted to the Council has been distributed on loan to selected research centres throughout Great Britain. Growths of the breast, cervix uteri, and buccal cavity are at present most favourable for radium therapy, but in rectal growths little success has attended the treatment. It is remarked that up to the present no method has been discovered by which malignant cells can be made more radium-sensitive, and that any advance in this direction would have wide-felt effects. Of cases of sarcoma, 23-50 per cent react favourably to radium treatment, and five cases of brain tumour have been treated, with two apparent successes.

\section{Physiology and the 'Aura'}

Is our issue of Feb. 6, p. 197, a note was published referring to Prof. D. F. Fraser-Harris's paper at a recent meeting of the British Psychological Society, in which he described the so-called human aura as the familiar negative after-image produced by temporal retinal induction. Dr. F. W. Edridge-Green has written pointing out that the phenomenon can be shown with white cardboard, and that it and " numerous others of a similar character are due to the movement of the photochemical fluid in the interretinal space. There appears to be a continuous flow towards the centre of the retina when the eyes are being used." We may add that Prof. E. N. da C. Andrade gave a humorous description of some experiments on this subject in Nature of Dec. 23, 1922, p. 843. Prof. Andrade used his hand and also cardboard hands and figures, and his conclusion was that the effects were due to after-images, an explanation given of a similar experiment referred to by Dr. Edridge-Green in NATURE of Dec. 9, 1922, p. 772.

\section{Palæontological Expedition to Northern India}

IT is reported by Science Service that an expedition organised by Yale University under Prof. Hellmut de Terra is proceeding to Northern India with the object of investigating the geology and palæontology of the Salt Range, one of the smaller mountain ranges of Northern India, situated about eighty miles south of the Himalayas. This range, which is con- sidered by some to be one of the key positions of Asia in the geological sense, is an area of great promise for these branches of research, as it has never been examined systematically for palæontological evidence. The expedition, it is hoped, may find there evidence bearing on the development of man. The members of the expedition, beside the leader, are Mrs. Hellmut de Terra, Prof. G. E. Hutchinson, and Mr. George E. Lewis.

\section{Announcements}

AT the anniversary meeting of the Royal Astronomical Society, held on Feb. 12, Dr. H. Knox-Shaw, Radeliffe Observer, Oxford, was re-elected president of the Society, and the new members of Council elected were Mr. C. R. Davidson, Sir Arthur Eddington, Mr. John Evershed, and Dr. R. Stoneley.

IT is announced in Science for Jan. 22 that the Richards Gold Medal for conspicuous achievement in chemistry has been awarded by the North-Eastern Section of the American Chemical Society to Prof. Arthur A. Noyes, director of the Gates Chemical Laboratory of the California Institute of Technology, Pasadena. The Richards Medal, which has thus been awarded for the first time, was established in 1929 to commemorate the contributions to chemistry by the late Prof. Theodore W. Richards, who was professor of chemistry in Harvard University. A trust fund of 10,000 dollars has been raised to endow tho medal.

WE have received a copy of a new catalogue of Zeiss surveying instruments from Messrs. Carl Zeiss, Mortimer Street, London, which includes details and illustrations of a number of levels, tacheometers, and theodolites, including the new Zeiss theodolite, type III. It is claimed that this instrument shows several improvements on previous models. The weight complete is only seventeen and a half pounds.

Applications are invited for the following appointments, on or before the dates mentioned:-A lecturer in pharmaceutics at the School of Pharmacy, Chelsea Polytechnic-The Principal, Chelsea Polytechnic, Manresa Road, S.W.3 (Feb. 24). An assistant aircraft inspector under the Government of IndiaThe High Commissioner for India, General Department, India House, Aldwych, W.C.2 (Feb. 25). A lecturer and instructor at the Royal Air Force Electrical and Wireless School, Cranwell, with knowledge of alternating current work and its application to high-frequency engineering--The Secretary, Air Ministry (Feb. 27). A full-time teacher in the Department of Mathematics and Physics of the West Ham Municipal College-The Principal, West Ham Municipal College, Romford Road, Stratford, E.15 (Feb. 27). A head of the Mechanical Engineering Department of the Coventry Technical CollegeThe Director of Education, Council House, Coventry (March 3). A professor of philosophy in the University College of North Wales, Bangor-The Secretary and Registrar, University College of North Wales, Bangor (May 14).

No. 3251, VoL. 129] 